\title{
Üniversite Öğrencilerinde Sosyal Medya Bağımlılığı ile Sosyal Ortamlarda Gelişmeleri Kaçırma Korkusu ve Yaşamın Anlamı Arasındaki Yordayıcı İlişkiler ${ }^{1}$
}

\author{
Merve KOCAK² ve Zeliha TRAȘ 3
}

Öz

$\mathrm{Bu}$ araştırmada, üniversite öğrencilerinin sosyal medya bağımlılı̆̆ ile sosyal ortamlarda gelişmeleri kaçırma korkusu ve yaşamın anlamı arasındaki yordayıcı ilişkilerin incelenmesi amaçlanmışır. Araştırmada ilişkisel tarama modeli kullanılmıștır. Araştırmanın çalısma grubu üniversite öğrencilerinden seçilmiştir. Araştırmaya 564 kı ve 167 erkek, toplamda 733 üniversite öğrencisi katılmıştır. Araştırmanın verileri Sosyal Medya Bağımlılı̆̆ı Ölçeği-Yetişkin Formu, Sosyal Ortamlarda Gelişmeleri Kaçırma Korkusu Ölçeği, Yaşamın Anlamı Ölçeği ve Kişisel Bilgi Formu kullanılarak toplanmıştır. Araştırmada; bağımsız örneklem t testi, One-Way Anova, Pearson Momentler Çarpımı Korelasyon Tekniği ve çoklu doğrusal regresyon analizi kullanılmıștır. Araştırmanın bulgularına göre, üniversite öğrencilerinin sosyal medya bağımlılı̆̆ ile cinsiyet değişkeni arasında anlamlı farklılık bulunmamıştır. Öte yandan üniversite öğrencilerinin sosyal medya bağımlılı̆ı ile anne-baba beraberlik, sosyal medya kullanımının uyku düzenini etkileme durumu, sosyal medyayı kullanım amaçları, hafta içi günlük ortalama sosyal medya kullanım süresi, hafta sonu günlük ortalama sosyal medya kullanım süresi değişkenlerine göre anlamlı farklılık bulunmuştur. Üniversite öğrencilerinin sosyal medya bağımlılığı ve sosyal ortamlarda gelişmeleri kaçırma korkusu arasında anlamlı ve orta düzeyde pozitif ilişki, sosyal medya bağımlılığı ve yaşamın anlamı arasında anlamlı ve düşük düzeyde negatif ilișki, sosyal ortamlarda gelişmeleri kaçırma korkusu ve yaşamın anlamı arasında anlamlı ve düşük düzeyde negatif ilişki tespit edilmiştir. Sosyal ortamlarda gelişmeleri kaçırma korkusu ve yaşamın anlamı, sosyal medya bağımlılı̆̆ını \%23 oranında yordamaktadır.

Anahtar Kelimeler: : Sosyal medya bağımlılı̆̆ı, sosyal ortamlarda gelişmeleri kaçırma korkusu, yaşamın anlamı

\section{Predictive Relationships Between Social Media Addiction, Fear of Missing Out and Meaning of Life in University Students}

\begin{abstract}
In this study, it was aimed to examine the predictive relationships between the social media addiction of university students and the fear of missing out on development in social environments and the meaning of life. Relational scanning model was used in the research. The study group of the research was selected from university students by simple random sampling method. A total of 733 university students, 564 girls and 167 boys, participated in the study. The data of the study were collected by using Social Media Addiction Scale-Adult Form, the Fear of Missing out Scale, Meaning of Life Scale and Personal Information Form. In the research; Independent sample t test, One-Way Anova, Pearson Product Moment Correlation Technique and multiple linear regression analysis were used. According to the findings of the study, no significant difference was found between the social media addiction of university students and the gender variable. On the other hand, a significant difference was found between university students' social media addiction and parents together, social media use affecting sleep patterns, purpose of using social media, average daily social media usage time on weekdays, average daily social media usage time on weekends. Significant and moderately positive relationship between university students' social media addiction and fear of missing out on developments in social environments, a significant and low level negative relationship between social media addiction and the meaning of life, a significant and low level negative relationship between fear of missing out on developments in social environments and the meaning of life have been found. . The fear of missing out on developments in social environments and the meaning of life predict social media addiction by $23 \%$
\end{abstract}

Key Words: Social Media Addiction, Fear of Missing Out (FoMO), Meaning of Life

\section{Atıf İçin / Please Cite As:}

Koçak, M., Traş, Z. (2021). Üniversite Öğrencilerinde Sosyal Medya Bağımlılığı ile Sosyal Ortamlarda Gelişmeleri Kaçırma Korkusu ve Yaşamın Anlamı Arasındaki Yordayıcı İlişkiler. Manas Sosyal Araștırmalar Dergisi, 10(3), 1618-1631.

Geliş Tarihi / Received Date: 08.03.2021

Kabul Tarihi / Accepted Date: 16.04.2021

\footnotetext{
${ }^{1}$ Bu çalışma Necmettin Erbakan Üniversitesi Eğitim Bilimleri Enstitüsü’ne bağlı olarak ilk yazarın ikinci yazar danışmanlığında 2021 yılında tamamladığı yüksek lisans tezine dayalı olarak hazırlanmıştır.

2 Uzm. Psi. Dan. MEB, 1kocakmerve@gmail.com

(D) ORCID: 0000-0003-4528-2761

3 Prof. Dr. Necmettin Erbakan Üniversitesi Ahmet Keleşoğlu Eğitim Fakültesi, zztras@gmail.com

(D)ORCID: 0000-0003-2670-0868
} 


\section{Giriş}

İnternetin en sık kullanım alanlarından biri olan sosyal medya (Tektaş, 2014, s. 852), kişilerin çevrim içi olarak fotoğraf, video, ses, yazı vb. paylaşımlarına ve yorum yapmalarına olanak tanıyan sosyal paylaşım sitelerinin genel adıdır. Sosyal medya, kişinin kendisine ait hikaye ve tecrübelerini kelimeler, resimler ve ses dosyaları olarak paylaştığı bir yapıdır. Başka deyişle sosyal medya, sadece bireylerin kendi hikayelerini paylaşmanın da ötesinde kurumların ürünlerini paylaşıp reklamlarını yaptıkları, haberlerin en çabuk yayıldığı en yeni ortamlardandır (Ünlü-Dalaylı, 2018, s. 33). Sosyal medyanın temeli, paylaşım yapmaya ve iletişime dayanmaktadır. Sosyal medya hem görsel temalardan hem de ses temalarından oluşmaktadır (Keskin ve Baş, 2015, s. 54). Bireylerin çift yönlü iletişsim kurmalarını sağlamaktadır. Sosyal medya ile yer ve zaman fark etmeksizin rahatlikla iletişim sağlanabilmektedir. Sosyal medyanın kullanılması basit ve sadedir, bu ağlar bireylerin rahatlıkla kullanabileceği şekilde tasarlanmıştır (Tekin, 2016, s. 29).

Bireyin sosyal medyada çok fazla zaman geçirdiği ve bu geçirdiği zamanın da gittikçe arttı̆̆ı, sosyal medyanın gündelik yaşamdaki okul, iş, arkadaşlarıyla ilişsisi gibi alanlarda olumsuz etkisinin olduğu durumlar için sosyal medya bağımlılığı kavramı kullanılmaktadır (Walker, 2011). Sosyal hayatta kabul görmeyen kişiler duygularından problemlerinden kaçmak, kendilerine bir kimlik oluşturmak ve kendilerini ispatlamak için bir grup kurmaktadır. Sanal sitelerde çok fazla vakit geçirip arkadaş çevrelerini genişletmektedirler (Kırık, Arslan, Çetinkaya \& Gül, 2015, p. 112). Bireylerin, sosyal becerilerindeki eksiklikler ve düşük benlik algıları nedeniyle gerçek hayattaki kişilerle iletişime geçmek yerine internet vasıtasıyla sosyal ortamlarda iletişime geçtiği belirtilmiştir. Yani kişinin sosyal becerilerindeki eksiklikler onun internet ve sosyal medya bağımlısı olmasına neden olmaktadır (Caplan, 2003, s. 628).

Başka bireylerin ne yaptığını denetleme arzusu ve bunları kaçırma korkusu, arkadaş eksikliği, sosyal medyanın bir mecburiyet haline gelmesinin sağladığı mutluluk duygusunun da sosyal medya bağımlılı̆̆ına neden olabileceği tespit edilmiştir. Sosyal medya bağımlılı̆̆ının ilk aşamasında bireyler genelde yaşamın kendiliğinden devam etmesi, arkadaşlık kurma ve sosyalleşme nedeniyle sosyal medyaya yöneldiklerini, sosyal medya bağımlılığının devamllık aşamasında ise bireyler var olan ilişkilerini sürdürmek için sosyal medyayı kullandıklarını ifade etmişlerdir (Aksoy, 2018, s. 864). Birey sosyal medya uygulamalarını sosyal ortamlarda gelişmeleri kaçırmamak için de bir araç olarak kullanabilmektedir. Sosyal ortamlarda gelişmeleri kaçırma korkusu, bireylerin sosyal medya uygulamaları ile aynı anda etkileşime geçebilmesi, daha çabuk ve kolay şekilde bireyin diğer kişilerin ne yaptığı bilgisine ulaşabilmesidir (Przybylski, Murayama, DeHaan ve Gladwell, 2013, s. 1841). Sosyal ortamlarda gelişmeleri kaçırma korkusunu deneyimleyen birey, diğer kişilerden haberdar olabilmek için sosyal medyada çevrim içi olma gereksinimi hissetmektedir (Alt, 2015, s. 111). Bu nedenle bireyin bu uygulamalarda zaman geçirme vakti artmaktadır.

Sosyal ağlar, özellikle gençlere, çeşitli etkinlikler, olaylar ve konuşmalar gibi gerçek zamanlı etkinliklere çok rahat ve hızlı ulaşım imkanı sağlamaktadır (Fox ve Moreland, 2015, s. 174). Genç kişiler bu bilgi yoğunluğu içinde günlerinin çoğunu sosyal ağlarda bilgi paylaşmakla, gündemi takip etmekle arkadaşlarının ve kendilerinin durumlarını güncellemekle geçirmektedirler (Fox ve Moreland, 2015, s. 170; Hato, 2013, p. 4). Sosyal ağlardan kaynağını alan bu sürekli güncelleme ve takip etme davranışı bütün dünyada Fear of Missing Out (FoMO) olarak adlandirlmaktadır (Hato,2013, p. 4; Przybylski vd., 2013; s. 1841). Sosyal ortamlarda gelişmeleri kaçırma korkusu, Amerikalı bilim insanları tarafindan tanımlanmış ve Türkçe'ye "gelişmeleri kaçırma korkusu" (GKK) olarak çevrilmiştir.

Internetin ve akıllı telefonların insan hayatında yer almasıyla birlikte kişilerin sosyal ağlarda gelişmelerden haberdar olamama ve gelişmeleri kaçırma korkusu yaşamaları sebebiyle sosyal ağlarda çok fazla zaman geçirmelerine neden olan yeni bir kavram olarak ortaya çıkmıştır. Sosyal ortamlarda gelişmeleri kaçırma korkusu, diğer insanların ne yaptı̆̆ ile sürekli bağlantıda olma arzusu ile ilgilidir (Dossey, 2014, p. 1; Przybylski vd., 2013, p. 1841). Przybylski, Murayama, DeHaan ve Gladwell (2013, p. 1847), yaptı̆̆1 çalışmada sosyal medya bağımlılı̆̆1 yüksek olan bireylerin sosyal ortamlarda gelişmeleri kaçırma korkusu yönelimlerinin de yüksek olduğunu ifade etmişlerdir. Diğer bir ifade ile sosyal ortamlarda gelişmeleri kaçırma korkusu ve sosyal medya bağımlılığ doğru orantılıdır. Sosyal ortamlarda gelişmeleri kaçırma korkusu olan kişiler sosyal ağlarda geçirdikleri vakit dışındaki hayatlarında sürekli yalnız hissettiklerini bildirmektedirler (Hato, 2013, p. 3). Sosyal medyanın hayatlarında olmadığı ve diğer insanların ne yaptığını takip edemeyen insanlar hissettikleri huzursuzluk, mutsuzluk duygularıyla yaşamlarını sorgulamaya, yaşamın anlamını düşünmeye yönelmektedirler. 
Yaşamın anlamı kavramı insanlık tarihinin geçmişi kadar eskidir (Adler, 2000, p. 7). Geçmişten şu ana kadar yaşamın anlamı için bilim insanları, teologlar, sanatçılar ve filozoflar görüşlerini söylemişlerdir. Bu sebeple de yaşamın anlamının ne olduğu konusunda verilen yanıtlar subjektif olmuştur (Yalom, 2001, p. 661). Yaşamın anlamı ile ilgili en önemli çalışmalar Adler'in araştırmalarında bulunmaktadır. Günümüzde gençler ve yaşlılar tarafindan sık sık yaşamın anlamı sorgulanmaktadır. Bu soruyu genellikle insanlar bir yenilgiye uğradıklarında sormaktadırlar. Hayatlarında iyi mesafe kateden, ağır sınavlardan geçmeyen insanlar böyle bir soruyla meşgul olmamaktadır (Adler, 2000, p. 13). Çağdaş kuramcılar yaşamda anlamın, kişinin yaşamını anlamlandırmasını ve bu hedefe yönelik ilerlemesini sağladığı düşüncesini savunmaktadır (Steger, 2012, p. 1). Sadece tek bir kişi için anlam taşıyan bir sözcük gerçekte anlamsızdır. Hedeflerimiz ve hareketlerimizde de durum böyledir. Buradaki biricik anlam, diğer insanlar için taşıdıkları anlamdır. Her birey önemli biri olmak için gayret eder fakat buradaki önemli nokta diğer insanlar için yapılan faydalı işlerden oluştuğunu fark etmemek yanılgısından başka bir şey değildir (Adler, 2000, p. 9).

Yaşamın anlamını arayan insanoğlu için anlam; hedef, değerler, idealler olmadan yaşamak ciddi olarak stres oluşturmaktadır (Yalom, 2001, p. 420). Her bireyin kendine has bir yaşam hedefi bulunmakla beraber bireyin, tavır ve tutumları, tüm haraketleri, alışkanlıkları, kişilik özellikleri bu anlamla uyum içindedir. Bireyin tüm davranışlarının temelinde dünyaya ve kendisine ilişkin önceden ayarlanmış bir fikir yatar. "Ben böyleyim ve evren de böyledir." yargısı bireyin yaşama verdiği anlamı yansıtır (Adler, 2000, p. 7). Günümüzde yaşamın anlamı kişide var olan anlam ve bulunmaya çalışılan anlam olarak iki şekilde sinıflandırmaktadır (Steger, Frazier, Oishi ve Kaler, 2006, p. 81). Yalom’a göre ise yaşamın anlamı kozmik anlam ve dünyevi anlam olarak ikiye ayrılmaktadır. Kozmik anlam, bireyin dışında ve onun üstünde var olan bir düzeni ifade etmektedir. Kainatın büyülü ya da ruhani düzeninden bahseder. Dünyevi anlam ise bütünüyle din dışı kaynakları oluşturmaktadır. Yani birey kozmik anlam olmadan kişisel anlama sahip olabilmektedir. Kozmik anlama sahip biri genelde ona uygun olan dünyevi anlamı yaşar. Bireyin dünyevi anlamı, kozmik anlamla uyumu ve bu anlamı yaşamayı içermektedir (Yalom, 2001, p. 656).

Yukarıda yer alan bilgiler doğrultusunda ilgili literatür incelendiğinde, sosyal medya bağımlılı̆̆ ile sosyal ortamlarda gelişmeleri kaçırma korkusu (Bloemen ve De Coninck, 2020, p.6; Ünal, 2019, s. 45) arasındaki ilişkinin incelendiği bazı çalışmalar mevcuttur. Aynı zamanda sosyal medya bağımlılığının cinsiyet (Andreassen, Pallesen ve Griffiths, 2017, p. 290; Baz,2018, s. 285), anne-baba beraberlik (Eligül, 2020, s. 33; Rücker, Akre, Berchtold ve Suris, 2015, p. 505), uyku düzeni (D’Souza ve Negahban, 2019, p. 5; Eroğlu ve Yıldırım, 2017, s. 8), hafta içi ve hafta sonu günlük ortalama sosyal medya kullanma süresi (Duman, 2019, s. 223; Ganjayeva, 2019, s. 65), sosyal medyay1 kullanım amaçları (Otu, 2015, p. 27; Tuğlu, 2017, s. 57) gibi çeşitli değişkenlere göre incelendiği bazı çalısmalar bulunmaktadır. Bu araştırmayla üniversite öğrencilerinin sosyal medya bağımlılık düzeylerini, sosyal ortamlarda gelişmeleri kaçırma korkusu ve yaşamın anlamı açısından incelemek ve sosyal ortamlarda gelişmeleri kaçırma korkusu ile yaşamın anlamının sosyal medya bağımlılık düzeylerini anlamlı düzeyde yordayıp yordamadığını ortaya koymak amaçlanmışır. Ancak sosyal medya bağımlılığ ile sosyal ortamlarda gelişmeleri kaçırma korkusu ve yaşamın anlamı arasındaki yordayıcı ilişkinin birlikte incelendiği çalışmaya rastlanılmamıştır. $\mathrm{Bu}$ çalışmanın ilgili literatüre bu yönüyle katkı sağlayacağı amaçlanmıştır.

$\mathrm{Bu}$ araştırmada sosyal medya bağımlılığı, sosyal ortamlarda gelişmeleri kaçırma korkusu ve yaşamın anlamı arasında anlamlı bir ilişki olup olmadığının incelenmesi amaçlanmıştır. Bu amaç doğrultusunda alt amaçlar geliştirilmiştir.

1. Üniversite öğrencilerinin sosyal medya bağımlllığı ölçeği puan ortalamaları cinsiyete göre anlamlı düzeyde farklılaşmakta mıdır?

2. Üniversite öğrencilerinin sosyal medya bağımlılı̆̆ ölçeği puan ortalamaları anne-baba beraberlik durumuna göre anlamlı düzeyde farklılaşmakta mıdır?

3. Üniversite öğrencilerinin sosyal medya bağımlılı̆̆1 ölçeği puan ortalamaları uyku düzenine göre anlamlı düzeyde farklılaşmakta mıdır?

4. Üniversite öğrencilerinin sosyal medya bağımlılı̆̆1 ölçeği puan ortalamalanı sosyal medyay1 kullanım amaçlarına göre anlamlı düzeyde farklılaşmakta mıdır?

5. Üniversite öğrencilerinin sosyal medya bağımlılı̆̆ ölçeği puan ortalamaları hafta içi sosyal medyayı kullanım süresine göre anlamlı düzeyde farklılaşmakta mıdır?

6. Üniversite öğrencilerinin sosyal medya bağımlılı̆̆ ölçeği puan ortalamaları hafta sonu sosyal medyayı kullanım süresine göre anlamlı düzeyde farklılaşmakta mıdır? 
7. Üniversite öğrencilerinin sosyal medya bağımlılı̆ı ölçeği puan ortalamaları ile sosyal ortamlarda gelişmeleri kaçırma korkusu ve yaşamın anlamı puan ortalamaları arasında anlamlı düzeyde bir ilişki var mıdır?

8. Üniversite öğrencilerinin sosyal medya bağımlllı̆̆ı ölçeği puan ortalamalarını sosyal ortamlarda gelişmeleri kaçırma korkusu ve yaşamın anlamı düzeyleri yordamakta mıdır?

\section{Yöntem}

Yapılan araştırma, ilişkisel tarama modeline göre gerçekleştirilmiştir. Tarama modeli, geçmişte olan ya da devam eden durumu olduğu gibi saptamayı amaçlayan modeldir. Araştırma konusu olan kişi, olay, nesne kendi koşulları içinde ve olduğu gibi tanımlanmaya çalışılır (Karasar, 2018, s. 109).

\section{Çalışma Grubu}

Araştırmanın çalışma grubu, 2019-2020 yllında Konya'da bulunan Necmettin Erbakan Üniversitesi öğrencilerinden seçilmiştir. Bu araştırma için Konya ili merkezinde bulunan Necmettin Erbakan Üniversitesi’ndeki öğrencilere 810 ölçek dağıtımı yapılmıştır. Bu anketlerin doldurulmasında eksik, boş olduğu fark edilen ve 25 yaş üstündeki öğrencilerin yer aldığı anketlerin veri girişi yapılmamıştır. Toplamda 733 veri, analize dahil edilmiştir. Çalsşma grubu 564’ü (\%76.9) kız ve 167’si (\%22.8) erkek öğrenciden oluşmaktadır. Öğrencilerin yaşları 17 ile 25 arasında değişmekte olup yaş ortalamaları 20.42'dir (ss=1.62). Öğrencilerin 237’si (\%32,7) 1.sınıf, 156's1 (\%21,5) 2.sınıf, 167’si (\%23) 3.sınıf, 105’i (\%14,5) 4.sınıf, 60’1 $(\% 8,3) 5$. sınıf ve üzeri öğrencilerden oluşmaktadır.

\section{Veri Toplama Araçları}

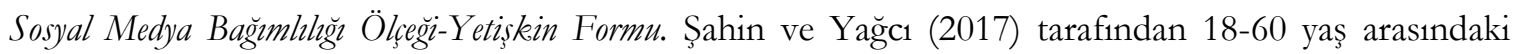
yetişkin bireylerin sosyal medya bağımlılık düzeylerini tespit etmek amacıyla geliştirilmiştir. Geçerlik çalışmaları doğrultusunda doğrulayıcı ve açımlayıcı analizler yapılmış ve Sosyal Medya Bağımlılığı ÖlçeğiYetişkin Formu'nun beşli likert tipi, 2 alt boyut (sanal tolerans ve sanal iletişim) ve 20 maddeden oluşan bir yapıda olduğu belirlenmiştir. Sanal tolerans alt boyutu 1-11. maddeler, sanal iletişim alt boyutu ise 12-20. maddelerden oluşmaktadır. Ölçekte 5. ve 11. maddeler ters puanlanmaktadır. Ölçeğin iki faktörlü yapısının doğrulanması amacıyla yapılan doğrulayıcı faktör analizinde Ki-kare değerinin $(\chi 2=7051.32$; sd=190, $\mathrm{p}=.00)$ anlamlı olduğu görülmüştür. Ölçeğin uyum indeksi değerleri ise $\chi 2 / \mathrm{sd}=3.05$, RMSA=.059, $\mathrm{SRMR}=.060, \mathrm{NFI}=.59, \mathrm{CFI}=.96$, GFI=.90; $\mathrm{AGFI}=.88$ ) olarak bulunmuştur. SMBÖ-YF'nun faktör yükleri .61 ile .87 arasında değerler almaktadır. Ölçeğin toplamı için Cronbach Alpha iç tutarlık katsayısı .94, sanal tolerans alt boyutu için .92 ve sanal iletişim için .91 olarak belirlenmiştir. Ölçeğin test-tekrar test güvenirlik katsayısı ölçeğin geneli için .93, sanal tolerans alt boyutu için .91 ve sanal iletişim alt boyutu için .90 olarak bulunmuştur. Yapılan analizler SMBÖ-YF’nun, yetişkinlerin sosyal medya bağımlılığını ölçmeye yönelik geçerli ve güvenilir bir ölçek olduğunu ortaya çıkarmıştır. Ölçekten alınabilecek en düşük puan 20, en yüksek puan 100'dür. Puanın yüksek olması kişinin kendisini "sosyal medya bağımlısı" olarak algıladığ1 şeklinde değerlendirilmektedir. Bu araştırma için Cronbach Alpha değeri .87'dir.

Sosyal Ortamlarda Gelismeleri Kaçrma Korkusu Ölçeği. Ölçeğin Türkçe güvenirlik ve geçerlik çalısması Gökler, Aydın, Ünal ve Metintaş (2016) tarafından uyarlanmıştır. Ölçek 18 yaş üstü yetişkin ve internet kullanıcılarına uygulanmıştır. Sosyal Ortamlarda Gelişmeleri Kaçırma Korkusu Ölçeği, Przybylski vd. (2013) tarafindan geliştirilmiştir. Tek boyuttan ve 10 maddeden oluşmaktadır. 5'li likert tipi bir ölçektir. Maddeleri 1= "hiç doğru değildir" ile 5= "aşırı şekilde doğrudur" arasında sıralanmıştır. Katılımcıların ölçekten aldıkları puan 10-50 arasında değer almaktadır ve kesim puanı yoktur. Ölçekten alınan puanın yüksek olması, bireyin gelişmeleri kaçırma korkusunun arttı̆̆ı anlamına gelmektedir. Sosyal Ortamlarda Gelişmeleri Kaçırma Korkusu Ölçeği'nin kapsam geçerliği puan1 .62 olarak bulunmuştur. GKKÖ'nün faktör yükleri .36-.77 arasında değişmektedir. Cronbach alfa katsayısı .81, test tekrar test güvenilirlik katsayısı .81 olarak bulunmuştur. Yapılan analizler sonucunda GKKÖ üniversite öğrencilerinde geçerli ve güvenilir bir ölçme aracı olduğunu ortaya çıarmıştır (Gökler vd., 2016). Bu araştırma için Cronbach Alpha değeri .81'dir.

Yaşamın Anlamı Ölçeği. Bu araştırmada yaşamın anlamını ölçmek için Steger, Frazier, Oishi ve Kaler (2006) tarafindan geliştirilen ve Demirdağ ve Kalafat (2015) tarafindan uyarlanan Yaşamın Anlamı Ölçeği kullanılmıştır. Yaşamın Anlamı Ölçeği’nin Türkçe ve İngilizce formlarındaki maddeler arasındaki korelasyon değerleri .74 ile .91 arasında bulunmuştur. Açımlayıcı faktör analizi sonucunda ölçekteki maddelerin toplam varyansın \% 68.2'sini açıkladığı görülmüştür. Ölçeğin madde toplam korelasyon 
katsayıları .44 ile .78, faktör yükleri ise .65 ile .88 arasında değer almaktadır. 7’li likert türü olan ölçme aracı Yaşamın Anlamı Ölçeği 10 maddeden oluşmaktadır. Ölçekteki maddelerin 9'u normal (1, 2, 3, 4, 5, 6, 7, 8 ve 10. maddeler), 1'i ters maddeden (9. madde) oluşmaktadır. Ölçekte var olan anlam (1, 4, 5, 6 ve 9. maddeler) ve bulunmaya çalşslan anlam $(2,3,7,8$ ve 10 . maddeler) olmak üzere iki alt boyuttan oluşmaktadır. Yaşamın Anlamı Ölçeğinin orijinal formunun güvenirliği için Steger vd. (2006), Cronbach alfa iç tutarlık katsayısını var olan anlam alt boyutu için $\alpha=.82$, bulunmaya çalışılan anlam alt boyutu için $\alpha=.87$ olarak bulmuştur. Ölçeğin Türkçe'ye uyarlamasının Cronbach alfa iç tutarlık katsayısı var olan anlam alt boyutu için $\alpha=.81$, bulunmaya çalışlan anlam alt boyutu için $\alpha=.85$ olarak saptanmıstır. Test tekrar test sonucunda ise bu puanlar sırasıyla .72 ve .76 olarak bulunmuştur. Ölçekten alınabilecek en fazla puan 70 ve en düşük puan $10^{\prime}$ dur. Ölçek puanının yüksek olması bireyin yaşam anlamına sahip olma düzeyinin de yüksek olduğunu ifade etmektedir. Bu araştırma için Cronbach Alpha değeri .75’tir.

Kişisel Bilgi Formu. Araştırmaya katılan kişilerden bazı genel bilgileri toplamak amacıyla araştırmacı tarafindan "Kişisel Bilgi Formu" hazırlanmıstır. Kişisel Bilgi Formu’nda üniversite öğrencilerinin cinsiyeti, yaşı, sınıf düzeyi, anne baba eğitim düzeyi, anne-baba beraberlik durumu, hafta içi ve hafta sonu sosyal medya hesaplarında geçirilen ortalama günlük süre, sosyal medyayı kullanım amaçları, sosyal medya kullanımının uyku düzenini etkileme durumu, öğrencilerin kullandığı sosyal medya hesapları gibi sorulara yer verilmiştir.

\section{Verilerin Analizi}

Verileri toplamak amacıyla Necmettin Erbakan Üniversitesi Eğitim Bilimleri Enstitüsünden gerekli izinleri aldıktan sonra üniversite öğrencilerine ulaşılmışır. Tesadüfü olarak belirlenen çalışma grubuna "Sosyal Medya Bağımlılığı Ölçeği-Yetişkin Formu”, "Sosyal Ortamlarda Gelişmeleri Kaçırma Korkusu Ölçeği", "Yaşamın Anlamı Ölçeğì" ve "Kişisel Bilgi Formu" uygulanmıştır. Öğrencilere uygulama sırasında, uygulamanın amacı hakkında bilgi verilmiş ve ölçeklerin yönergeleri okunmuştur. Uygulama yaklaşık 15-20 dk kadar sürmüştür. Araştırma sonucunda elde edilen veriler SPSS 20.0 paket programı kullanılarak analiz edilmiştir. Verilerin analizinde bağımlı değişkenle ilişkili iki ya da daha çok bağımsız değişkene bağlı olarak bağımlı değişkenin tahmin edilmesine yönelik analiz olan çoklu doğrusal regresyon kullanılmıştır. Ölçeklerden elde edilen puanlar arasındaki korelasyon, Pearson Korelasyon katsayısı kullanılarak hesaplanmıştır. İlişkisiz iki örneklem ortalamaları arasındaki farkın anlamlı olup olmadığını test etmek için bağımsız örneklem $\mathrm{t}$ testi, ilişkisiz iki veya daha çok örneklem ortalaması arasında farkın anlamlı olup olmadığını test etmek için de One Way Anova kullanılmıştır (Büyüköztürk, 2018, s. 49).

\section{Bulgular}

Tablo 1. Değģskenlere Ait Çarpıklık ve Basıklık Değerleri

\begin{tabular}{lcc}
\hline & Çarpıklık & Basıklık \\
\hline Sosyal Medya Bağımlılı̆̆ı Ölçeği-Yetişkin Formu & .096 & -.381 \\
Sosyal Ortamlarda Gelişmeleri Kaçırma Korkusu Ölçeği & .370 & -.316 \\
Yaşamın Anlamı Ölçeği & .209 & .410 \\
\hline
\end{tabular}

Araştırmada kullanılan, ölçeklerden alınan puanların normal dağılım gösterip göstermediğini belirlemek için çarpıklık ve basıklık katsayıları kontrol edilmiştir. Tablo 1'de görüldügü gibi değişkenlerin çarpıklık ve basıklık değerleri +1 ile -1 arasında yer almaktadır. Sonuçlar normal dağılım olduğunu göstermektedir (Hair, Black, Babin, Anderson ve Tatham, 2006, p. 74-76).

Tablo 2. Cinsiyete Göre Sosyal Medya Bağımlliğğ Puanlarmin t Testi İle Karşılaşstrilması

\begin{tabular}{|c|c|c|c|c|c|c|c|}
\hline & Cinsiyet & $n$ & $A O$ & $S$ & $s d$ & $t$ & $p$ \\
\hline \multirow{2}{*}{ Sosyal Medya Bağımlılığı } & $\mathrm{K}_{12}$ & 564 & 50.22 & 12.72 & 729 & .944 & .346 \\
\hline & Erkek & 167 & 49.18 & 12.25 & & & \\
\hline
\end{tabular}

Tablo 2 incelendiğinde, üniversite öğrencilerinin cinsiyet değişkenine göre sosyal medya bağımlıllğı ölçeği puan ortalamalarının anlamlı düzeyde farklılaşıp farklılaşmadığı bağımsız örneklem t testi ile incelenmiştir. Yapılan analiz sonucunda üniversite öğrencilerinin cinsiyet değişkenine göre sosyal medya bağımlılığı puan ortalamaları arasında anlamlı fark bulunmamıştır $(\mathrm{p}=.346, \mathrm{p}>.05)$. 
Tablo 3. Anne-Baba Beraberlike Durumuna Göre Sosyal Medya Bağımlılı̆̆ Puanlarmm t Testi İle Karşılaştırlması

\begin{tabular}{|c|c|c|c|c|c|c|c|}
\hline & $\begin{array}{c}\text { Anne-Baba Beraberlik } \\
\text { Durumu }\end{array}$ & $n$ & $A O$ & $S$ & $s d$ & $t$ & $P$ \\
\hline Sosyal Medya & Beraber & 554 & 49.12 & 12.26 & 593 & 2.326 & .020 \\
\hline Bağ́mlılığ & Ayr1 & 41 & 53.73 & 12.09 & & & \\
\hline
\end{tabular}

Tablo 3 incelendiğinde, üniversite öğrencilerinin anne-baba beraberlik durumu değişkenine göre sosyal medya bağımlılı̆̆ı ölçeği puan ortalamalarının anlamlı düzeyde farklılaşıp farklılaşmadığı bağımsız örneklem $t$ testi ile incelenmiştir. Yapılan karşılaştırmalar sonucunda üniversite öğrencilerinin anne-baba beraberlik durumu değişkenine göre sosyal medya bağımlılığı ölçeği puan ortalamaları $(p=.020, p<.05)$ arasında anlamlı fark bulunmuştur. Anne babası ayrı olanların $(\mathrm{AO}=53.73)$, beraber olanlara göre $(\mathrm{AO}=49.12)$ sosyal medya bağımlılığı puan ortalamaları anlamlı düzeyde yüksektir.

Tablo 4. Uyku Düzenine Göre Sosyal Medya Bağımlılŭ̆ Puanlarnnı t Testi İle Karşılasstırlması

\begin{tabular}{lllllllc}
\hline & Uyku Düzeni & $\boldsymbol{n}$ & $\boldsymbol{A O}$ & $\boldsymbol{S}$ & $\boldsymbol{s d}$ & $\boldsymbol{t}$ & $\boldsymbol{P}$ \\
\hline \multirow{2}{*}{ Sosyal Medya Bağımlılığı1 } & Hayır & 463 & 46.19 & 11.73 & 724 & 11.510 & .000 \\
& Evet & 263 & 56.53 & 11.47 & & & \\
\hline
\end{tabular}

$* \mathrm{p}<.05$

Tablo 4 incelendiğinde, üniversite öğrencilerinin uyku düzeni durumu değişkenine göre sosyal medya bağımlılığı ölçeği puan ortalamalarının anlamlı düzeyde farklılaşıp farklılaşmadığı bağımsız örneklem t testi ile incelenmiştir. Yapılan karşılaştırmalar sonucunda üniversite öğrencilerinin uyku düzeni durumu değişkenine göre sosyal medya bağımlılı̆̆ ölçeği puan ortalamaları $(\mathrm{p}=.000, \mathrm{p}<.05)$ arasında anlamlı farkll1ık bulunmuştur. Uyku düzenini etkileyenlerin $(\mathrm{AO}=56.53)$, uyku düzenini etkilemeyenlere göre $(\mathrm{AO}=46.19)$ sosyal medya bağımlılı̆̆ puan ortalamaları anlamlı düzeyde yüksektir.

Tablo 5. Sosyal Medya Bă̆ımlıh̆̆ın Sosyal Medyayı Kullamım Amacına Göre Anova Sonuçlar

\begin{tabular}{|c|c|c|c|c|c|c|c|c|}
\hline & $\begin{array}{l}\text { Sosyal Medyayı } \\
\text { Kullanım Amacı }\end{array}$ & $n$ & $A O$ & $S$ & $s d$ & $F$ & $p$ & $\begin{array}{c}\text { Anlaml1 } \\
\text { Fark }\end{array}$ \\
\hline & 1) Sosyal Amaçlı & 228 & 53.25 & 11.84 & 720 & 10.888 & .000 & $1-2$ \\
\hline & 2) Arkadaşlarla İletişim & 156 & 47.64 & 11.00 & & & & $1-4$ \\
\hline Sosyal Medya & 3) Vakit Geçirme & 216 & 51.69 & 12.65 & & & & $1-5$ \\
\hline \multirow[t]{3}{*}{ Bağımlilığ1 } & 4) Bilgi Edinme & 58 & 42.31 & 11.77 & & & & $2-3$ \\
\hline & 5) Gündemi Takip & 56 & 47.17 & 12.52 & & & & $3-4$ \\
\hline & Toplam & 714 & 48.41 & 12.46 & & & & \\
\hline
\end{tabular}

Tablo 5. incelendiğinde, üniversite öğrencilerinin Sosyal Medya Bağımlığı Ölçeği puan ortalamalarına bakıldığında en yüksek puanı sosyal medyayı, sosyal amaçlı kullanan öğrencilerin $(A O=53.25)$ aldığ1 görülmektedir. Ardından sırasıyla vakit geçirme $(\mathrm{AO}=51.69)$, arkadaşlarla iletişim $(\mathrm{AO}=47.64)$, gündemi takip $(\mathrm{AO}=47.17)$ ve bilgi edinme $(\mathrm{AO}=42.31)$ amacıyla sosyal medyayı kullanan öğrenciler gelmektedir. Üniversite öğrencilerinin Sosyal Medya Bağımlılığı ölçeğinden aldıkları puanların sosyal medyayı kullanım amaçları değişkenine göre anlamlı düzeyde farklılaştığ1 $(\mathrm{p}<.05)$ görülmektedir. Birimler arası farkların hangi gruplar arasında olduğunu belirlemek için yapılan Tukey testinin sonuçlarına göre sosyal medya kullanım amaçları arasındaki farkın; sosyal amaçlı ile arkadaşlarla iletişim, bilgi edinme ve gündemi takip amaçlı kullanım arasında, arkadaşlarla iletişim ve vakit geçirme amaçlı kullanım arasında, vakit geçirme ve bilgi edinme amaçlı kullanım arasında olduğu görülmektedir.

Tablo 6. Sosyal Medya Bağımlılı̆̆nın Hafta içi Kullanım Süresine Göre Anova Sonuçlar

\begin{tabular}{|c|c|c|c|c|c|c|c|c|}
\hline & Hafta içi Kullanım Süresi & $n$ & $A O$ & $S$ & $s d$ & $F$ & $p$ & $\begin{array}{c}\text { Anlamli } \\
\text { Fark }\end{array}$ \\
\hline \multirow{5}{*}{$\begin{array}{l}\text { Sosyal Medya } \\
\text { Bağımlılığı }\end{array}$} & 1) 1 saatten az (0-60 dk) & 128 & 41.80 & 11.97 & \multirow[t]{5}{*}{708} & \multirow[t]{5}{*}{36.235} & \multirow[t]{5}{*}{.000} & $1-2$ \\
\hline & 2) $1-3$ saat $(61-180 \mathrm{dk})$ & 334 & 49.35 & 11.18 & & & & $1-3$ \\
\hline & 3) 3-5 saat $(181-300 \mathrm{dk})$ & 158 & 55.02 & 12.47 & & & & $1-4$ \\
\hline & 4) 5 saat üzeri (301 dk ve üzeri) & 89 & 55.00 & 12.00 & & & & $2-3$ \\
\hline & Toplam & 709 & 49.96 & 12.57 & & & & $2-4$ \\
\hline
\end{tabular}

${ }^{*} \mathrm{p}<.05$

Tablo 6. incelendiğinde, üniversite öğrencilerinin Sosyal Medya Bağımlığı Ölçeği puan ortalamalarına bakıldığında en yüksek puanı sosyal medyayı hafta içi 3-5 saat arası $(\mathrm{AO}=55.02)$ ve 5 saat üzeri 
$(\mathrm{AO}=55.00)$ kullanan öğrencilerin aldığı görülmektedir. Ardından sırasıyla hafta içi 1-3 saat $(\mathrm{AO}=49.35)$ ve 1 saatten az $(\mathrm{AO}=41.80)$ sosyal medyay1 kullanan üniversite öğrencileri gelmektedir. Üniversite öğrencilerinin Sosyal Medya Bağımlılı̆̆1 Ölçeğinden aldıkları puanların sosyal medyayı hafta içi kullanım süresi değişkenine göre anlamlı düzeyde farklılaştığı $(\mathrm{p}<.05)$ görülmektedir. Birimler arası farkların hangi gruplar arasında olduğunu belirlemek için yapılan Tukey testi sonuçlarına göre hafta içi sosyal medya kullanım süreleri arasındaki farkın; 1 saatten az sosyal medya kullanımı ile 1-3 saat, 3-5 saat, 5 saat üzeri sosyal medyayı kullanım süreleri arasında; 1-3 saat sosyal medya kullanımı ile 3-5 saat, 5 saat üzeri sosyal medya kullanım süreleri arasında olduğu görülmektedir.

Tablo 7. Sosyal Medya Bağımlılı̆̆ınn Hafta sonu Kullanım Süresine Göre Anova Sonuclar

\begin{tabular}{|c|c|c|c|c|c|c|c|c|}
\hline & Hafta sonu Kullanım Süresi & $n$ & $\boldsymbol{A O}$ & $\boldsymbol{S}$ & $s d$ & $F$ & $p$ & $\begin{array}{c}\text { Anlamli } \\
\text { Fark }\end{array}$ \\
\hline & 1) 1 saatten az $(0-60 \mathrm{dk})$ & 295 & 39.77 & $\lfloor 1.51$ & 705 & 50.961 & .000 & $1-2,1-3$ \\
\hline Sosyal & 2) $1-3$ saat $(61-180 \mathrm{dk})$ & 1258 & 47.52 & 10.49 & & & & $1-4,2-3$ \\
\hline Medya & 3) 3-5 saat (181-300 dk) & 2190 & 52.87 & 12.01 & & & & $2-4,3-4$ \\
\hline \multirow[t]{2}{*}{ Bağımlılığı } & 4) 5 saat üzeri (301 dk ve üzeri) & 5163 & 56.48 & 12.04 & & & & \\
\hline & Toplam & 7706 & 49.99 & 12.57 & & & & \\
\hline
\end{tabular}

${ }^{*} \mathrm{p}<.05$

Tablo 7. incelendiğinde, üniversite öğrencilerinin Sosyal Medya Bağımlığı Ölçeği puan ortalamalarına bakıldığında en yüksek puanı sosyal medyayı hafta sonu 5 saat üzeri kullanan öğrencilerin $(\mathrm{AO}=56.48)$ aldığı görülmektedir. Ardından sirasiyla hafta sonu 3-5 saat $(\mathrm{AO}=52.87), 1-3$ saat $(\mathrm{AO}=47.52)$ ve 1 saatten az $(\mathrm{AO}=39.77)$ sosyal medyayı kullanan üniversite öğrencileri gelmektedir. Üniversite öğrencilerinin Sosyal Medya Bağımlılığı Ölçeğinden aldıkları puanların sosyal medyayı hafta sonu kullanım süresi değişkenine göre anlamlı düzeyde farklılaşttğı $(\mathrm{p}<.05)$ görülmektedir. Birimler arası farkların hangi gruplar arasında olduğunu belirlemek için yapılan Tukey testinin sonucuna göre hafta sonu sosyal medya kullanım süreleri arasındaki farkın; 1 saatten az sosyal medya kullanımı ile 1-3 saat, 3-5 saat, 5 saat üzeri sosyal medya kullanım süreleri arasında; 1-3 saat sosyal medya kullanımı ile 3-5 saat, 5 saat üzeri sosyal medya kullanım süreleri arasında; 3-5 saat sosyal medya kullanımı ile 5 saat üzeri sosyal medya kullanım süreleri arasında olduğu görülmektedir.

Tablo 8. Üniversite Öğrencilerinde Sosyal Medya Bă̆ımlih̆̆g, Sosyal Ortamlarda Gelişmeleri Kaçırma Korkusu ve Yasamın Anlamı Arasindaki İlişkinin Korelasyon Sonuclar

\begin{tabular}{lccc}
\hline & $\begin{array}{c}\text { Sosyal Medya } \\
\text { Bağımlı̆̆ğ1 }\end{array}$ & $\begin{array}{c}\text { Sosyal Ortamlarda } \\
\text { Gelişmeleri Kaçırma Korkusu }\end{array}$ & Yaşamın Anlamı \\
\hline Sosyal Medya Bağımlılı̆̆1 & 1 & $.451^{* *}$ & $-.238^{* *}$ \\
Sosyal Ortamlarda Gelişmeleri & $.451^{* *}$ & 1 & $-.121^{* *}$ \\
Kaçırma Korkusu & $-.238^{* *}$ & $-.121^{* *}$ & 1 \\
Yaşamın Anlamı & & &
\end{tabular}

Tablo 8 incelendiğinde, üniversite öğrencilerinin sosyal medya bağımlllŭı ölçeğinden aldıkları puan ortalamaları ile sosyal ortamlarda gelişmeleri kaçırma korkusu ölçeğinden aldıkları puan ortalamaları arasında $(\mathrm{r}=.451, \mathrm{p}<.01)$ anlamlı ve orta düzeyde pozitif ilişki ortaya çıkarken, üniversite öğrencilerinin sosyal medya bağımlılı̆̆ ölçeğinden aldıkları puan ortalamaları ile yaşamın anlamı ölçeğinden aldıkları puan ortalamaları arasında $(\mathrm{r}=-.238, \mathrm{p}<.01)$ anlamlı ve düşük düzeyde negatif ilişki olduğu ortaya çıkmıştır. Üniversite öğrencilerinin sosyal ortamlarda gelişmeleri kaçırma korkusu ölçeğinden aldıkları puan ortalamaları ile yaşamın anlamı ölçeğinden aldıkları puan ortalamaları arasında $(r=-.121, p<.01)$ anlamlı ve düşük düzeyde negatif ilişki ortaya çıkmıştır.

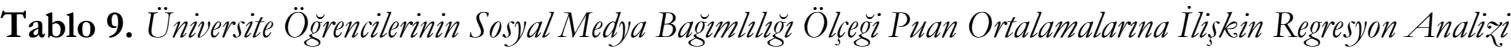
Sonuclar

\begin{tabular}{lllll}
\hline & $\boldsymbol{B}$ & $\begin{array}{c}\text { Standart } \\
\text { Hata }\end{array}$ & $\boldsymbol{\beta}$ & $\boldsymbol{t}$ \\
\hline $\begin{array}{l}\text { Sosyal Ortamlarda Gelişmeleri } \\
\text { Kaçırma Korkusu }\end{array}$ & .798 & .061 & .428 & 13.148 \\
Yaşamın Anlamı & & & & -5.704 \\
\hline $\mathrm{R}=0.487 ; \mathrm{R}^{2}=0.23$ & -.223 & .039 & -.186 & \\
\hline
\end{tabular}


Tablo 9. incelendiğinde sosyal ortamlarda gelişmeleri kaçırma korkusu ve yaşamın anlamı değişkenleriyle birlikte üniversite öğrencilerinin sosyal medya bağımlllı̆̆ puanları anlamlı bir ilişki vermektedir ( $\mathrm{R}=.487, \mathrm{R}^{2}=.23, \mathrm{p}<.001$ ). Sosyal medya bağımlilığ ölçeği toplam puan1, sosyal ortamlarda gelişmeleri kaçırma korkusu ile yaşamın anlamı ölçeğine ilişkin toplam varyansın \%23’ünü yordamaktadır. Standardize edilmiş regresyon katsayısına $(\beta)$ göre bağımsız değişkenlerin sosyal medya bağımlılı̆̆1 üzerindeki göreli önem sırası; sosyal ortamlarda gelişmeleri kaçırma korkusu $(\beta=.428, t=13.148, p<.001)$ ve yaşamın anlamıdır $(\beta=-.186, \mathrm{t}=-5.704, \mathrm{p}<.001)$.

\section{Tartışma, Sonuç ve Öneriler}

Yapılan araştırmada üniversite öğrencilerinde sosyal medya bağımlılığı puan ortalamaları cinsiyet değişkenine göre anlamlı düzeyde farklılaşmamaktadır. İlgili literatür incelendiğinde araştırma bulgusunu destekler nitelikte araştırmaların olduğu görülmektedir (Aliusta, Akmanlar ve Gökkaya, 2019; Baz, 2018; Beyler, 2019; Demir, 2019; Duman, 2019; Macit, 2019; Ümmet, Batal, Kaya ve Alkan, 2019; Deniz ve Gürültü, 2018). Buna karşın sosyal medya bağımlılığı ile cinsiyet arasında anlamlı farklılaşmanın olduğu çalışmalar da mevcuttur (Arslan, 2019; Baş ve Diktaş, 2020; Çelik, 2017; Kıran, Küçükbostancı ve Emre, 2020). Yurt dışındaki çalışmalara bakılırsa Chung, Morshidi, Yoong ve Thian (2019, p. 64), kadın olmanın, sosyal medyada daha fazla zaman geçirmenin ve psikopati ölçeğinden daha fazla puan almanın daha yüksek bağımllık düzeyleri ile ilişkili olduğunu ortaya koymuştur. Alnjadat, Hmaidi, Samha, Kilani ve Hasswan (2019, p. 392), üniversite öğrencilerinde erkeklerin kadınlara göre daha fazla sosyal medya bağımlısı olduğu bulunmuştur. Andreassen, Pallesen ve Griffiths (2017, p. 291), kadın olanların sosyal medya bağımlılı̆̆ ile daha yüksek puanlarla ilişkili olduğunu ortaya koymuştur.

Yapılan araştırmada üniversite öğrencilerinde anne baba beraberlik durumuna göre sosyal medya bağımlılı̆̆ı ölçeği puan ortalamaları arasında anlamlı fark bulunmuştur. İlgili literatür incelendiğinde; Eligül (2020, s. 33), anne baba birlikte olanların internet bağımlılık ölçeğine göre internet bağımlllı̆ı düzeyinin daha düşük olduğu görülmektedir. Buna karşın sosyal medya bağımlılık düzeylerinin anne baba birliktelik durumuna göre anlamlı düzeyde farklılaşmadığını ortaya koyan araştırmalar da bulunmaktadır (Bilginer, 2020). Yurt dışındaki çalışmalara bakılacak olursa, Rücker, Akre, Berchtold ve Suris (2015, p. 505), anne babası beraber yaşamayan kullanıcıların problemli internet kullanımına sahip olma olasılığının daha yüksek olduğu bulunmuştur.

Yapılan araştırmada üniversite öğrencilerinin uyku düzeni durumu değişkenine göre sosyal medya bağımlılığı ölçeği puan ortalamaları anlamlı düzeyde farklılaşmaktadır. Literatür incelendiğinde; Eroğlu ve Yıldırım (2017, s. 8), üniversite öğrencilerinde yaptığı çalışmada uyku kalitesi ve sosyal medya ağları bağımlılığı ölçek puanları anlamlı farklılık göstermektedir. Güneş, Akbıyık, Aypak ve Görpelioğlu (2018, s. 189), 16-19 yaş arası lise öğrencilerinde facebook bağımlılık ölçeği düzeyi arttıkça uyku kalitesinin bozulduğu sonucuna varılmıştır. Yurt dışındaki çalışmalara bakılırsa Rosen, Carrier, Miller, Rokkum ve Ruiz (2016, p. 4)'in, 700'den fazla üniversite öğrencisiyle yaptığ1 teknolojinin uyku düzeni üzerindeki etkisine ilişkin son araştırmasında, çalışmaya katılan öğrencilerin yarısının mobil telefonları açık halde uyuduğu ve pek çoğunun gece en azından bir kere uyanıp gelen mesaj ve bildirimleri kontrol ettiğine işaret etmekte, bir şeyleri kaçırma kaygısı ve teknolojiye bağımlılık hissi gece uykularını etkilemektedir. Wong vd. (2020, p. 6), üniversite öğrencilerinde hem internette oyun oynama bozukluğu hem de sosyal medya bağımlılı̆̆nın şiddeti daha çok psikolojik sıkıntı ve daha düşük uyku kalitesiyle ilişkili bulunmuştur. D’Souza ve Negahban (2019, p. 5), Instagram bağımlılığı arttıkça üniversite öğrencilerinin uyku kalitesi önemli ölçüde azalmaktadır. Xanidis ve Brignell (2016, p. 123), sosyal ağ sitelerine artan bağımlılığın uyku kalitesinin azalması ve günlük bilişsel başarısızlıkların artmasıyla ilişkili olduğunu göstermiştir.

Yapılan araştırmada üniversite öğrencilerinin sosyal medya bağımlılığı ölçeğinden aldıkları puanların sosyal medyayı kullanım amaçları değişkenine göre anlamlı düzeyde farklılaşttğı bulunmuştur. $\mathrm{Bu}$ farklılaşma sırasıyla; sosyal ve arkadaşlarla iletişim, sosyal ve bilgi edinme, sosyal ve gündemi takip etme, arkadaşlarla iletişim ve vakit geçirme, vakit geçirme ve bilgi edinme arasında olduğu görülmektedir. Literatür incelendiğinde; İnce ve Koçak (2017, s. 743), üniversite öğrencilerinin sosyal medyaya yönelten nedenler arasında; eğlenme ve rahatlama isteği, arkadaşlarla iletişimde bulunmak ve çeşitli konularda bilgi sahibi olma isteği ilk sıralarda yer almaktadır. Aksoy (2018, p. 864), katılımcıların sosyal medyayı kullanma nedenleri; arkadaş eksikliği, sosyal medyanın sosyal gerekliliği, doyum duygusu, kaçırma korkusu, sosyal medya ve günlük yaşamın iç içe geçmesi olduğunu göstermiştir. Ayrıca bireylerin arkadaş bulamama, sosyalleşme eksikliği ve yaşamın tekdüzeliği gibi nedenlerle sosyal medyayı kullanmaya yöneldiklerini tespit 
etmiştir. Yurt dışındaki çalışmalara bakılırsa Otu (2015, p. 27), üniversite öğrencileri arasındaki sosyal medya bağımlılığını araştırdığı çalışmada öğrencilerin çoğu \%29’u sosyal medyay1 eğlence için kullanmaktadır. \%22,3’ü medya içeriği oluşturmak ve paylaşmak için, \%20.3'ü yeni kişilerle tanışmak, $\% 18,4$ 'ü sosyal etkinlikler için ve $\% 10$ 'u ilişkileri sürdürmek için sosyal medya kullanmaktadır. Idubor (2015, p. 291), en yaygin erişilebilen sosyal medya ağlarından Facebook ve Twitter, arkadaşlarla buluşurken (\%78.2), haber alırken (\%67.9), iletişimde (\%66.5) ve çevrim içi öğrenme (\%54.0) gibi amaçlarla lisans öğrencileri tarafindan kullanılmaktadır.

Yapılan araştırmada, hafta içi sosyal medyayı kullanım süresine göre sosyal medya bağımlllı̆ı ölçeği puan ortalamaları arasında anlamlı fark bulunmuştur. Öğrencilerin Sosyal Medya Bağımlığı Ölçeği puan ortalamalarına bakıldığında en yüksek puanı sosyal medyayı hafta içi 3-5 saat arası ve 5 saat üzeri kullanan öğrenciler almıştır. Ardından sırasıyla, 1-3 saat arası ve 1 saatten az sosyal medyada vakit geçiren öğrenciler gelmektedir. Hafta sonu sosyal medyayı kullanım süresine göre sosyal medya bağımlılığı ölçeği puan ortalamaları arasında anlamlı fark bulunmuştur. Sosyal Medya Bağımlığı Ölçeği puan ortalamalarına bakıldığında en yüksek puanı sosyal medyayı hafta sonu 5 saat üzeri kullanan öğrencilerin ardından sirasıyla hafta sonu sosyal medyay1 3-5 saat arası, 1-3 saat aras1 ve 1 saatten az kullanan öğrencilerin aldığ1 görülmektedir. Literatür incelendiğinde; Kırık vd. (2015, p. 118), Türkiye'deki gençlerde sosyal medya bağımlılığ düzeyi üzerine nicel bir araştırma adlı çalışmasında günlük frekans sosyal medya profillerini ziyaret etme oranı bağımlılıkta önemli farklılık oluşturmaktadır. Sosyal medya bağımlılık düzeyi internette geçirilen günlük zaman durumunda da artış gösterir. Gün içinde sıklıkla sosyal medya profillerine ziyaret de bağımlılığ artırmaktadır. Duman (2019, s. 223), bireylerin sosyal medya bağımlılığı günlük kullanım süresine göre anlamlı düzeyde farklilaşmaktadır. Sosyal medya kullanım süresi arttıkça sosyal medya bağımlilığı da artmaktadır. İnce ve Koçak (2017, s. 743), katılımcıların günlük bir oturumda sosyal medya kullanım sürelerine bakıldığında, bir oturumda kullanım süresi en az 3 dakika, en fazla kullanım süresi 340 dakika olarak bulunmuştur. Bir oturumda sosyal medya kullanım sürelerinin ortalaması 47.41'dir. Yurt dışındaki çalışmalara bakılırsa Ganjayeva (2019, s. 65), üniversite öğrencilerinde sosyal medya bağımlillğ̆, Eysenck'in kişilik envanteri ve özgüven arasındaki ilişkiyi incelediği araştırmasında günlük ortalama 1-3 saat sosyal medyada zaman harcayan bireylerin ortalaması, 1 saatten az vakit geçiren bireylerin ortalamasından anlamlı düzeyde yüksektir. 3 saatten fazla vakit geçiren bireylerin ortalaması, 1 saatten az ve 1-3 saat vakit geçiren bireylerin ortalamalarından anlamlı şekilde yüksektir. Otu (2015, p. 28), üniversitesi öğrencileri arasındaki sosyal medya bağımlılığını araştırdığı çalışmada öğrencilerin günlük olarak sosyal medyada harcadıkları vakitte; bireylerin çoğu (\%35) günlük dört veya daha fazla saat sosyal medyada vakit geçirmektedir. \%15,5’i günde 3 saat, \%17'si 2 saat, \%17'si 1 saat ve \%15,5’i bir saatten daha az sosyal medyada vakit geçirmektedir.

Yapılan araştırmada, üniversite öğrencilerinin sosyal medya bağımlılı̆̆1 ve sosyal ortamlarda gelişmeleri kaçırma korkusu arasında anlamlı ve orta düzeyde pozitif ilişki bulunmuştur. Literatür incelendiğinde bu konuda tutarlı sonuçların olduğu görülmektedir (Hamutoğlu, Topal ve Gezgin, 2020). Çevrim içi sosyal destek ve gelişmeleri kaçırma korkusu ile sosyal anksiyete bozukluğu belirti düzeyi arasındaki ilişkinin açıklanmasında sosyal medya bağımlilığı ve sosyal medya yorgunluğunun aracı rolünün araştırıldığ1 çalışmada, gelişmeleri kaçırma korkusu ile sosyal medya bağımlılığı arasında pozitif yönde anlamlı bir ilişki bulunmuştur (Ünal, 2019, s. 45). Traş ve Öztemel (2019, s. 97), Facebook yoğunluğu puanları ile gelişmeleri kaçırma korkusu ve akıllı telefon bağımlılığ arasında pozitif yönde anlamlı ilişki saptamıştır. Yurt dışındaki çalışmalara bakılırsa; Pontes, Taylor ve Stavropoulos (2018, p. 4), sosyal ortamlarda gelişmeleri kaçırma korkusu sosyal ağ siteleri bağımlılı̆ııı anlamlı düzeyde yordamaktadır. Kacker ve Saurav (2020, p. 135), sosyal ortamlarda gelişmeleri kaçırma korkusu, sosyal medya bağımlılı̆̆1 ve psikolojik faktörler arasında pozitif yönde anlamlı bir ilişki bulunmaktadır. Franchina, Vanden Abeele, Van Rooij, Lo Coco ve De Marez (2018, p. 12), FoMO, hem gençlerin çeşitli sosyal medya platformlarını ne sıklıkla kullandıklarının hem de aktif olarak kaç platformu kullandıklarının pozitif bir yordayıcısı olarak bulunmuştur. Sosyal ortamlarda gelişmeleri kaçırma korkusu, facebook ve snapchat gibi daha özel sosyal medya platformlarının güçlü bir öngörücüsü olarak bulunmuştur. Putri ve Halimah (2019, p. 529), Instagram kullanıcılarının sosyal medya bağımlılığı ile sosyal ortamlarda gelişmeleri kaçırma korkusu arasında pozitif bir ilisski bulunmaktadır. Pratiwi ve Fazriani (2020, p. 123), sosyal medya kullanıcılarında sosyal ortamlarda gelişmeleri kaçırma korkusu ile sosyal medya bağımlılığı arasında anlamlı bir ilişki bulunmaktadır. Varchetta, Fraschetti, Mari ve Giannini (2020, p. 8), sosyal ağlar, sosyal ortamlarda gelişmeleri kaçırma korkusu ve sosyal ağlara bağımlılık arasında pozitif bir ilişki bulunmuştur. 
Yapılan araştırmada, üniversite öğrencilerinin sosyal medya bağımlılığı ve yaşamın anlamı arasında anlamlı ve düşük düzeyde negatif ilişki bulunmuştur. Literatür incelendiğinde bu konuda benzer sonuçların olduğu görülmektedir (Balcı ve Koçak, 2017; Çınar ve Mutlu, 2019). Yurt dışındaki çalışmalara bakılırsa Hawi ve Samaha (2017), sosyal medyanın bağımlılık oluşturan kullanımının yaşam doyumu ile pozitif bir ilişkiye sahip olduğunu bulmuştur.

\section{Sinirlilıklar}

$\mathrm{Bu}$ araştırmanın birtakım sınırlılıkları bulunmaktadır. Araştırmadan elde edilen veriler 2019-2020 y1lı Konya ilinde bir devlet üniversitesinde öğrenim gören üniversite öğrencilerinden elde edilen sonuçlar ve araştırmaya katılan öğrencilerin ölçek formlarına verdikleri yanıtlar ile sınırlıdır.

\section{Öneriler}

Bu araştırmanın örneklemi yaş ortalaması 20.42 olan 17 ile 25 yaş aralığındaki üniversite öğrencileriyle sınırlıdır. Benzer araştırmaların bu aralık dışındaki yaş gruplarına da yapılması konu ile ilgili daha geniş boyutlu bir bilgiye ulaşılmasını sağlayacaktır. Yapılacak araştırmalarda sosyal medya bağımlılık düzeyi farklı değişkenlere göre incelenerek sosyal medya bağımlılı̆̆na ilişkin daha detaylı bilgiler elde edilebilir. Bireylerin sosyal medya bağımlılığının, süreç içindeki gelişiminin saptanmasında yapılacak olan boylamsal çalışmaların önemli olduğu düşünülmektedir. Sosyal medya bağımlılı̆̆ını artıran veya azaltan durumlar düşünülerek deneysel çalışmalar yapılabilir. Literatür incelendiğinde sosyal medya bağımlıllğı, sosyal ortamlarda gelişmeleri kaçırma korkusu ve yaşamın anlamı arasındaki ilişkinin incelendiği herhangi bir araştırmaya rastlanılmamıştır. Bu değişkenlerle yapılacak olan araştırmalarla bu çalışmayı destekleyen veya desteklemeyen sonuçlar elde edilebilir. Sosyal medya bağımlllğı konusunda üniversite öğrencilerini bilgilendirmek, bilinçlendirmek için üniversitelerde seminerler ve konferanslar verilebilir. Öğrencilerin sosyal medya bağımlısı olmasını önlemek, azaltmak adına sosyal ve kültürel faaliyetlere ağırlık verilebilir, konserler, geziler düzenlenebilir. Üniversitelerde PDR merkezleri aracıllğıyla önleme çalışmaları yapılabilir, bunun için PDR merkezleri yaygınlaştırlabilir.

\section{Etik Beyan}

"Üniversite Öğrencilerinde Sosyal Medya Băğmlhh̆̆ ile Sosyal Ortamlarda Gelișmeleri Kaçırma Korkusu ve Yaşamm Anlamı Arasındaki Yordayıc İlişkiler" başlıklı çalışmanın yazım sürecinde bilimsel kurallara, etik ve alıntı kurallarına uyulmuş; toplanan veriler üzerinde herhangi bir tahrifat yapılmamış ve bu çalışma herhangi başka bir akademik yayın ortamına değerlendirme için gönderilmemiştir. Necmettin Erbakan Üniversitesi Sosyal ve Beşeri Bilimler Bilimsel Araştırmalar Etik Kurulu Başkanlığı Etik Kurul Karar’ına göre "18/12/2020" tarihinde "03" toplantı sayısı, "2020/122" karar no ile etik kurul izni alınmıştır. SMBÖ-YF, GGKÖ ve YAÖ kullanılabilmesi için ölçek sahiplerinden gerekli izinler alınmıştır.

\section{Kaynakça}

Adler, A. (2000). Yaşamm anlam ve amac (Çev: K. Şipal). İstanbul: Say Yayınları.

Aksoy, M. E. (2018). A qualitative study on reasons for social media addiction. European Journal of Educational Research, 7(4), 861-865. Erişim Adresi: https://www.eu-jer.com/a-qualitative-study-on-the-reasons-for-social-mediaaddiction

Aliusta, Z., Akmanlar, Z. ve Gökkaya, F. (2019). Üniversite öğrencilerinin iletişim becerileri ve sosyal medya bağımlılığı arasındaki ilişkinin incelenmesi. Anadolu Psikiyatri Dergisi, 20(1), 10-13. doi: 10.5455/apd.302644847

Alnjadat, R., Hmaidi, M. M., Samha, T. E., Kilani, M. M. \& Hasswan, A. M. (2019). Gender variations in social media usage and academic performance among the students of University of Sharjah. Journal of Taibah University Medical Sciences, 14(4), 390-394. https://doi.org/10.1016/j.jtumed.2019.05.002

Alt, D. (2015). College students' academic motivation, media engagement and fear of missing out. Computers in Human Behavior, 49, 111-119. https://doi.org/10.1016/j.chb.2015.02.057

Andreassen, C. S., Pallesen, S. \& Griffiths, M. D. (2017). The relationship between addictive use of social media, narcissism, and self-esteem: Findings from a large national survey. Addictive behaviors, 64, 287-293. https://doi.org/10.1016/j.addbeh.2016.03.006

Arslan, A. (2019). Ortaöğretim Öğrencilerinin Dijital Bağımlılık Düzeylerinin Çeşitli Değişkenler Açısından İncelenmesi: Sivas İli Örneği. Gaz̧i Eğitim Bilimleri Dergisi, 5(2), 63-80. Erişim Adresi: https://dergipark.org.tr/tr/pub/gebd/issue/47331/537903

Aypak, C., Akbıyık, D. İ., Güneş, N. A. ve Görpelioğlu, S. (2018). Lise öğrencilerinde sosyal medya bağımlllı̆̆1 ve uyku kalitesi. Türkiye Aile Hekimliği Dergisi, 22(4), 185-192. doi: 10.15511/tahd.18.00475 
Balc1, Ș. ve Koçak, M. C. (2017). Sosyal medya kullanım ile yașam doyumu arasındaki ilișki: Üniversite öğrencileri üzerinde bir araştırma. Uluslararası İletişimde Yeni Yönelimler Konferansı (ss. 34-45). İstanbul, Türkiye. Erişim Adresi: https://hdl.handle.net/11467/1598

Baş, K. ve Diktaş, A. (2020). Social Media Dependency of Pre-Service Social Studies Teachers. Inonu University Journal of the Faculty of Education, 21(1), 193-207. doi: 10.17679/inuefd.563544

Baz, F. Ç. (2018). Sosyal medya bağımlılı̆̆1: Üniversite öğrencileri üzerine çalışma. OPUS Uluslararası Toplum Araștirmalarn Dergisi, 9(16), 276-295. doi: 10.26466/opus.470118

Beyler, B. (2019). Akdeniz. Bölgesinde sosyal medya bağrmhlĭğ ve bă̆lanma ilişkisinin incelenmesi. (Yüksek Lisans Tezi). Üsküdar Üniversitesi, Sosyal Bilimler Enstitüsü, İstanbul.

Bilginer, A. (2020). Lise ögrencilerinde sosyal medya bă̆gmlĭğ ile özyeterlik düzeyi arasındaki iliskinin incelenmesi: Mardin ili örneği. (Yüksek Lisans Tezi). Çağ Üniversitesi, Sosyal Bilimler Enstitüsü, Mersin.

Bloemen, N. \& De Coninck, D. (2020). Social media and fear of missing out in adolescents: The role of family characteristics. Social Media + Society, 6(4), 1-11. https://doi.org/10.1177/2056305120965517

Büyüköztürk, S.. (2018). Sosyal bilimler için veri analiz̧ el kitabı. Ankara: Pegem Akademi.

Caplan, S. E. (2003). Preference for online social interaction: A theory of problematic internet use and psychosocial well-being. Communication Research, 30(6), 625-648. doi:10.1177/00936502032578423

Chung, K. L., Morshidi, I., Yoong, L. C. \& Thian, K. N. (2019). The role of the dark tetrad and impulsivity in social media addiction: Findings from Malaysia. Personality and Individual Differences, 143, 62-67. https://doi.org/10.1016/j.paid.2019.02.016

Çelik, M. (2017). Üniversite ögrencilerinin sosyal medya bağımllhk düzeylerinin incelenmesi: Kültür Üniversitesi ögrencileri üzerinde bir araştırma. 1. Uluslararası İletişimde Yeni Yönelimler Konferansı (ss. 1-10). İstanbul, Türkiye. Erişim Adresi: http://acikerisim.ticaret.edu.tr/xmlui/bitstream/handle/11467/1594/M00796.pdf?sequence=1\&isAllowed=y

Çınar, Ç. Y. ve Mutlu, E. (2019). İnternet bağımlılı̆̆ının benlik saygısı, dikkat, gelişmeleri kaçırma korkusu, yaşam doyumu ve kişilik özellikleri ile ilişkisi. Bağımlllk Dergisi, 20(3), 133-142. Erişim Adresi: https://dergipark.org.tr/tr/pub/bagimli/issue/45814/577995

D’Souza, L. \& Negahban, M. B. (2019). Instagram virtual network addiction and sleep quality among students pursuing a speech and hearing course. Interdisciplinary Journal of Virtual Learning in Medical Sciences, 10(1), 1-10. doi: $10.5812 /$ ijvlms.89059

Demir, B. (2019). Akdeniz. Bölgesi’nde sosyal medya bağımlilŭg ve kişisel iyi oluş ilişkisinin incelenmesi. (Yüksek Lisans Tezi). Üsküdar Üniversitesi, Sosyal Bilimler Enstitüsü, İstanbul.

Demirdağ, S. ve Kalafat, S. (2015). Yaşamın anlamı ölçeği (YAÖ): Türkçeye uyarlama, geçerlik ve güvenirlik çalışması. Inönü Üniversitesi Eğitim Fakültesi Dergisi, 16(2), 83-95. do1: 10.17679/iuefd.16250801

Denï, L. ve Gürültü, E. (2018). Lise öğrencilerinin sosyal medya bağımlılıkları. Kastamonu Eğitim Dergisi, 26 (2) , 355 367. doi: $10.24106 /$ kefdergi.389780

Dossey L. (2014). FoMO, digital dementia, and our dangerous experiment. Explore: The Journal of Science and Healing, 2(10), 69-73. doi: 10.1016/j.explore.2013.12.008.

Duman, Ö. D. (2019). Sosyal medya bağımhlh̆gr: Eræurum ili üzerine bir inceleme. (Doktora Tezi). Atatürk Üniversitesi, Sosyal Bilimler Enstitüsü, Erzurum.

Eligül, F. (2020). Algzlanan ebeveyn tutumlarmmn internet bağımlil̆ğ ve akademik başar ile ilişkisinin incelenmesi. (Yüksek Lisans Tezi). İstanbul Gelişim Üniversitesi, Lisansüstü Ĕ̆itim Enstitüsü, İstanbul.

Eroğlu, O. ve Yıldırım, Y. (2017). Sosyal medya ağlarının kullanım amacı ve bağımlılığının uyku kalitesi ile ilişkisinin incelenmesi. Türkiye Spor Bilimleri Dergisi,1(1), 1-10. Erişim $\quad$ Adresi: https://dergipark.org.tr/tr/pub/tusbid/issue/33463/368462

Fox, J. \& Moreland, J. J. (2015). The dark side of social networking sites: An exploration of the relational and psychological stressors associated with Facebook use and affordances. Computers in Human Behavior, 45, 168176. https://doi.org/10.1016/j.chb.2014.11.083

Franchina, V., Vanden Abeele, M., Van Rooij, A. J., Lo Coco, G. \& De Marez, L. (2018). Fear of missing out as a predictor of problematic social media use and phubbing behavior among Flemish adolescents. International journal of environmental research and public health, 15(10), 1-18. https:// doi.org/10.3390/ijerph15102319

Ganjayeva, N. (2019). Üniversite ögrencilerinde sosyal medya bağımllĭğ, Eysenck'in kiş̧ilik envanteri ve özgüven arasindaki ilişkinin incelenmesi. (Yüksek Lisans Tezi). Üsküdar Üniversitesi, Sosyal Bilimler Estitüsü, İstanbul.

Gökler, M. E., Aydın, R., Ünal, E. ve Metintaş, S. (2016). Sosyal ortamlarda gelişmeleri kaçırma korkusu ölçeğinin türkçe sürümünün geçerlilik ve güvenilirliğinin değerlendirilmesi. Anadolu Psikizatri Dergisi, 17, 53-59. Erişim Adresi: https://toad.halileksi.net/olcek/sosyal-ortamlarda-gelismeleri-kacirma-korkusu-olcegi

Hair, J. F., Black, W. C., Babin, B. J., Anderson, R. E. \& Tatham, R. L. (2006). Multivariate Data Analysis, 6, 69-72. New Hersey: Hoboken. Erişim Adresi: https://www.scirp.org/(S(lz5mqp453edsnp55rrgjct55))/reference/ReferencesPapers.aspx?ReferenceID=17472 15

Hamutoğlu, N. B., Topal, M. ve Gezgin, D. M. (2020). Investigating Direct and Indirect Effects of Social Media Addiction, Social Media Usage and Personality Traits on FoMO. International Journal of Progressive Education, 16(2), 248-261. doi: https://doi.org/10.29329/ijpe.2020.241.17

Hato, B. (2013). Mobile phone checking behavior out of a fear of missing out: Development, psychometric properties and test-retest reliability of a C-FoMO-scale. (Master's Thesis). Faculty of Humanities Tilburg University. ANR: 610304 
Hawi, N. S. \& Samaha, M. (2017). The relations among social media addiction, self-esteem, and life satisfaction in university students. Social Science Computer Review, 35(5), 576-586. https://doi.org/10.1177/0894439316660340

Idubor, I. (2015). Investigating social media usage and addiction levels among undergraduates in University of Ibadan, Nigeria. Journal of Education, Society and Behavioural Science, 7(4), 291-301. https://doi.org/10.9734/BJESBS/2015/15808

İnce, M. ve Koçak, M. C. (2017). Üniversite öğrencilerinin sosyal medya kullanım alışkanlıkları: Necmettin Erbakan Üniversitesi örneği. Karabüle Üniversitesi Sosyal Bilimler Enstitüsü Dergisi,7(2), 736-749. Erişim Adresi: https://dergipark.org.tr/tr/pub/joiss/issue/32387/360236

Kacker, P. \& Saurav, S. (2020). Correlation of missing out (FoMO), anxiety and aaggression of young $\begin{array}{llll}\text { adults. International Journal } & \text { Research-Granthalayah, } & 8(5), & 138 .\end{array}$ https://doi.org/10.29121/granthaalayah.v8.i5.2020.107

Karasar, N. (2018). Bilimsel algz çerçevesi ile bilimsel araștırma yöntemi. Ankara: Nobel Yayıncilık.

Keskin, S. ve Baş, M. (2015). Sosyal medyanın tüketici davranışları üzerine etkisinin belirlenmesi. Gað̨i Üniversitesi İktisadi ve İdari Bilimler Fakültesi Dergisi, 17 (3), 51-69. Erişim Adresi: https://dergipark.org.tr/tr/pub/gaziuiibfd/issue/28305/300777

Kıran. S., Küçükbostanc1, H. ve Emre, İ. E. (2020). Sosyal medya kullanımının kişiler üzerindeki etkilerinin incelenmesi. Bilişim Teknolojileri Dergisi, 13(4), 435-441. https://doi.org/10.17671/gazibtd.693331

Kırık, A. M., Arslan, A., Çetinkaya, A. \& Gül, M. (2015). "A Quantitative Research on the Level of Social Media Addiction among Young People in Turkey". International Journal of Science Culture and Sport (IntJSCS), 3(3), 108122. Erişim Adresi: http://www.intjscs.com/Makaleler/671028450_3c3s_11.pdf

Macit, H. (2019). Marmara Bölgesi’nde Sosyal Medya Băğmlilğg Bulunan Bireylerin Psikolojile Semptomlarmmn Incelenmesi. (Yüksek Lisans Tezi). Üsküdar Üniversitesi, Sosyal Bilimler Enstitüsü, İstanbul.

Otu, A. A. (2015). Social Media Addiction among Students of the University of Ghana. (Doktora Tezi). Univesity of Ghana, Ghana.

Pontes, H. M., Taylor, M. \& Stavropoulos, V. (2018). Beyond "Facebook Addiction": The Role of Cognitive-Related Factors and Psychiatric Distress in Social Networking Site Addiction. Cyberpsychology, Behavior, and Social Networking, 21(4), 240-247. doi:10.1089/cyber.2017.0609

Pratiwi, A. \& Fazriani, A. (2020). Hubungan antara fear of missing out (FoMO) dengan kecanduan media sosial pada remaja pengguna media sosial. Jurnal Kesehatan, 9(1), 119-130. https://doi.org/10.37048/kesehatan.v9i1.123

Przybylski, A. K., Murayama, K., DeHaan, C. R. \& Gladwell, V. (2013). Motivational, emotional, and behavioral correlates of fear of missing out. Computers in Human Behavior, 29(4), 18411848. https://doi.org/10.1016/j.chb.2013.02.014

Putri, AID ve Halimah, L. (2019). Hubungan FoMO dengan Adiksi Media Sosial pada Mahasiswa Pengguna Instagram di Universitas Islam Bandung. Prosiding Psikologi, 5(2), 525-532. Erişim Adresi: http://karyailmiah.unisba.ac.id/index.php/psikologi/article/view/17131

Rosen, L., Carrier, L.M., Miller, A., Rokkum, J. \& Ruiz, A. (2016). Sleeping with technology: cognitive, affective, and technology usage predictors of sleep problems among college students. Sleep Health, 2(1), 49-56. do1: 10.1016/ j.sleh.2015.11.003

Rücker, J., Akre, C., Berchtold, A. \& Suris, J. C. (2015). Problematic Internet use is associated with substance use in young adolescents. Acta paediatrica, 104(5), 504-507. https://doi.org/10.1111/apa.12971

Steger, M. F. (2012). Experiencing meaning in life: Optimal functioning at the nexus of spirituality, psychopathology and wellbeing. In P. T. P. Wong (Ed.), The human quest for meaning, 2, 165-184. New York, NY: Routledge. Erişim Adresi:https://www.scirp.org/(S(i43dyn45teexjx455qlt3d2q))/reference/ReferencesPapers.aspx?ReferenceID= 1160003

Steger, M. F., Frazier, P., Oishi, S. \& Kaler, M. (2006). The meaning in life questionnaire: Assessing the presence of and search for meaning in life. Journal of Counseling Psychology, 53, 80-93. doi: 10.1037/0022-0167.53.1.80

Şahin, C. ve Yağc1, M. (2017). Sosyal medya bağımlılığ ölçeği-yetişkin formu: Geçerlilik ve güvenirlik çalışması. Ahi Evran Üniversitesi Krrşehir Eğitim Fakültesi Dergisi (KEFAD), 18(1), 523-538. Erişim Adresi: https:/ / toad.halileksi.net/olcek/sosyal-medya-bagimliligi-olcegi-yetiskin-formu

Tekin, H. (2016). Ortaokul ögrencilerinin sosyal medya kullanım ile algzlanan insani değerlerin incelenmesi (Yüksek Lisans Tezi). Adıyaman Üniversitesi, Sosyal Bilimler Enstitüsü, Adıyaman.

Tektaş, N. (2014). Üniversite öğrencilerinin sosyal ağları kullanmalarına yönelik bir araştırma. Tarih Okulu Dergisi, 7(17), 851-870. http://dx.doi.org/10.14225/Joh474

Traş, Z. ve Öztemel, K. (2019). Facebook yoğunluğu, gelişmeleri kaçırma korkusu ve akıllı telefon bağımlılı̆̆1 arasındaki ilişkinin incelenmesi. Addicta: The Turkish Journal on Addictions, 6(1), 91-113.

Tuğlu, B. (2017). Ortaokul öğrencilerinin sosyal medyayn kullanm amaçlar ve sosyal medya kullanımlarna ilişkin tutumlarn (Yüksek Lisans Tezi). Sakarya Üniversitesi, Ĕ̆itim Bilimleri Enstitüsü, Sakarya.

Ümmet, D., Batal, Ö., Kaya, A. ve Alkan, H. (2019). Fark.h Yaş Gruplarnndaki Bireylerde Sosyal Medya Bağımlilı̆g: Çeşitli Değiskeenlere Göre Bir Incelenme. 21.Uluslararası Psikolojik Danışma ve Rehberlik Kongresi (ss. 328-334).

Ünal, Ç. (2019). Cevrimiçi sosyal destek ve gelişmeleri kaçırma korkusu ile sosyal anksiyete bozukluğu belirti düzeyi arasindaki iliskkinin açıklanmasinda sosyal medya bağımllh̆̆g ve sosyal medya yorgunluğunun aracı rolü (Yüksek Lisans Tezi). Başkent Üniversitesi, Sosyal Bilimler Enstitüsü, Ankara. 


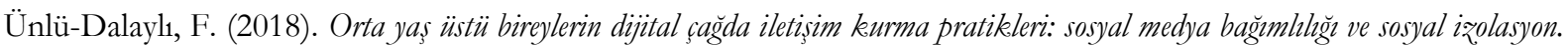
(Yüksek Lisans Tezi). Marmara Üniversitesi, Sosyal Bilimler Enstitüsü, İstanbul.

Varchetta, M., Fraschetti, A., Mari, E. \& Giannini, A. M. (2020). Adicción a redes sociales, Miedo a perderse experiencias (fomo) y Vulnerabilidad en línea en estudiantes universitarios. Revista Digital de Investigación en Docencia Universitaria, 14(1), 1-13. http://dx.doi.org/10.19083/ridu.2020.1187

Walker, L. (2011). What Is Social Networking Addiction? Erişim Adresi: http://personalweb. about.com/od/socialmediaaddiction/a/Social-Networking-Addiction.htm, Erişim Tarihi: 18.05.2020.

Wong, H. Y., Mo, H. Y., Potenza, M. N., Chan, M. N. M., Lau, W. M., Chui, T. K., ... \& Lin, C. Y. (2020). Relationships between severity of internet gaming disorder, severity of problematic social media use, sleep quality and psychological distress. International Journal of Environmental Research and Public Health, 17(6), 113. https://doi.org/10.3390/ijerph17061879

Xanidis, N. \& Brignell, C. M. (2016). The association between the use of social network sites, sleep quality and cognitive function during the day. Computers in Human Behavior, 55, 121-126. https://doi.org/10.1016/j.chb.2015.09.004

Yalom, I. (2001). Varolusşu psikoterapi. (Çev: Z. İyidoğan-Babayiğit). İstanbul: Kabalcı Yayınevi.

\section{EXTENDED ABSTRACT}

Social media, one of the most common areas of use of the Internet (Tektaş, 2014, p. 852), allows people to share photos, videos, sounds, articles, etc. online. It is the general name of social networking sites that allow them to share and comment. Social media is a structure where a person shares his / her own stories and experiences as words, pictures and sound files. In other words, social media is one of the newest environments where individuals share and advertise their products beyond just sharing their own stories (Ünlü-Dalayli, 2018, p. 33). The concept of social media addiction is used for situations where the individual spends a lot of time on social media and this time increases gradually, and social media has a negative effect in daily life such as school, work, relationship with friends (Walker, 2011). People who are not accepted in social life form a group to escape from their emotions and problems, create an identity for themselves and prove themselves. They spend a lot of time on virtual sites and expand their circle of friends (Kurık, Arslan, Çetinkaya, \& Gül, 2015, p. 112). It has been stated that individuals communicate in social environments via the internet instead of communicating with real-life people due to their lack of social skills and low self-perception. In other words, deficiencies in the social skills of the person cause him to be addicted to internet and social media (Caplan, 2003, p. 628).

Social networks provide very convenient and fast access to real-time activities such as various activities, events and speeches, especially for young people (Fox, \& Moreland, 2015, p. 174). Young people spend most of their days sharing information on social networks, following the agenda and updating the status of their friends and themselves in this intensity of information (Fox, \& Moreland, 2015, p. 170; Hato, 2013, p. 4). This continuous update and follow-up behavior originating from social networks is called Fear of Missing Out (FoMO) all over the world (Hato, 2013, p. 4; Przybylski et al., 2013, p. 1841). The fear of missing out on developments in social environments has been defined by American scientists and translated into Turkish as "fear of missing out on developments" (GKK). With the inclusion of the internet and smart phones in human life, it has emerged as a new concept that causes people to spend too much time in social networks due to the fear of not being aware of the developments in social networks and missing the developments. The fear of missing out on developments in social settings is related to the desire to be in constant connection with what other people are doing (Dossey, 2014, p. 1; Przybylski et al., 2013, p. 1841). Przybylski, Murayama, DeHaan, and Gladwell (2013, p. 1847) stated in their study that individuals with high social media addiction have a high fear of missing out on developments in social environments. In other words, the fear of missing the developments in social environments and social media addiction are directly proportional.

People who are afraid of missing out on developments in social environments report that they always feel lonely in their lives other than the time they spend in social networks (Hato, 2013, p. 3). People who do not have social media in their lives and who cannot follow what other people are doing tend to question their lives and think about the meaning of life with feelings of uneasiness and unhappiness. The concept of the meaning of life is as old as the past of human history (Adler, 2000, p. 7). Scientists, theologians, artists and philosophers have spoken their views about the meaning of life from past to present. For this reason, the answers given about what the meaning of life is were subjective (Yalom, 2001, p. 661). The most important studies about the meaning of life are in Adler's research.

In this study, it was aimed to examine the predictive relationships between the social media addiction of university students and the fear of missing out on developments in social environments and the 
meaning of life. Relational scanning model was used in the research. The study group of the research was chosen from the students of Necmettin Erbakan University in Konya in 2019-2020.

For this research, 810 scales were distributed to the students at Necmettin Erbakan University in the city center of Konya. In the filling of these questionnaires, the data of the questionnaires, which were found to be incomplete and empty and that included students over the age of 25 , were not entered. A total of 733 data were included in the analysis. A total of 733 university students, 564 girls and 167 boys, participated in the study. The data of the study were collected by using Social Media Addiction ScaleAdult Form, the Fear of Missing out Scale, Meaning of Life Scale and Personal Information Form. During the application, the students were informed about the purpose of the application and the instructions of the scales were read. The application took about 15-20 minutes. The data obtained as a result of the research were analyzed using the SPSS 20.0 package program. In the research; Independent Sample t test, One-Way Anova, Pearson Product Moment Correlation Technique and multiple linear regression analysis were used.

As a result of the research, no significant difference was found in the social media addiction mean scores of university students according to the gender variable. According to the relationship between parents, the social media addiction scale mean scores are significantly higher in those whose parents are separated than those whose parents are together. The social media addiction score averages of university students, whose use of social media affects sleep patterns, is significantly higher than students whose sleep patterns are not affected. Social media addiction score averages of university students who use social media for social purposes; It differs significantly according to the average scores of university students who use it for spending time, communicating with friends, following the agenda and obtaining information. Social media addiction score averages of university students who use social media for over 5 hours and 3-5 hours a day during the week; It significantly differs according to the average scores of university students who use social media for 1-3 hours and less than 1 hour per day. Social media addiction score averages of university students who use social media for an average of more than 5 hours a day at the weekend; It significantly differentiates according to the average scores of university students who use social media for 3-5 hours, 1-3 hours and less than 1 hour daily. Significant and moderately positive correlations between university students' social media addiction and fear of missing out on developments in social environments, a significant and low-level negative relationship between social media addiction and the meaning of life, a significant and low-level negative relationship between fear of missing out on developments in social environments and the meaning of life were found. . A significant relationship was found between social media addiction, fear of missing out on social media, and the meaning of life. Fear of missing out on developments in social environments and the meaning of life predict social media addiction by $23 \%$.

The sample of this study is limited to university students between the ages of 17 and 25 with an average age of 20.42. Conducting similar studies on age groups outside this range will provide access to a wider range of information on the subject. More detailed information about social media addiction can be obtained by examining the level of social media addiction according to different variables. Longitudinal studies to determine the development of social media addiction of individuals in the process are thought to be important. Experimental studies can be done by considering situations that increase or decrease social media addiction. When the literature is examined, no research has been found that examines the relationship between social media addiction, fear of missing out on developments in social environments and the meaning of life. With researches to be conducted with these variables, results that support or do not support this study can be obtained. Seminars and conferences can be held at universities to inform and raise awareness of university students about social media addiction. In order to prevent or reduce students' social media addiction, social and cultural activities can be emphasized, concerts and trips can be organized. Prevention studies can be carried out through psychological counseling and guidance centers in universities, and psychological counseling and guidance centers can be expanded for this. 